\title{
Spór o opodatkowanie kolei linowych i wyciągów narciarskich. Uwagi na tle wyroku NSA z dnia 9 lipca 2019 r., II FSK 2693/17
}

\author{
Dispute over taxation of cableways and ski lifts. Comments against the judgment \\ of the Supreme Administrative Court of 9 July 2019, II FSK 2693/17 \\ Спор о налогообложении канатных дорог и горнолыжных подъемников. \\ Комментарии в связи с постановлением Высшего Административного Суда \\ от 9 июля 2019 года, II FSK 2693/17
}

\author{
BOGUMIŁ PAHL \\ Dr hab., prof. Uniwersytetu Warmińsko-Mazurskiego w Olsztynie \\ e-mail: bogumilpahl@op.pl, https://orcid.org/0000-0003-4089-7580
}

\begin{abstract}
Streszczenie: Tematyka opodatkowania podatkiem od nieruchomości infrastruktury narciarskiej wywołuje na etapie stosowania przepisów ustawy o podatkach i opłatach lokalnych liczne wątpliwości interpretacyjne. Spowodowane jest to brakiem jednoznacznej definicji pojęcia "budowla" na potrzeby opodatkowania podatkiem od nieruchomości. Obowiązująca od 2003 r. legalna definicja tego terminu ma charakter odsyłający. W ustawie podatkowej nie zdecydowano się wymienić obiektów uznanych za budowle lecz zawarto odesłanie do przepisów prawa budowlanego. Te z kolei zaś w wielu przypadkach są nieprecyzyjne. W efekcie prowadzi to do różnych, często odmiennych rozstrzygnięć organów podatkowych oraz sądów administracyjnych. Jest to szczególnie zauważalne w przypadku obiektów budowlanych o złożonej strukturze konstrukcyjnej.
\end{abstract}

Słowa kluczowe: koleje linowe, wyciągi narciarskie, opodatkowanie, podatek od nieruchomości, wykładnia terminu "budowla"

Summary: The subject of real estate tax on ski infrastructure raises numerous interpretation doubts at the stage of application of the provisions of the Act on Local Taxes and Fees. This is due to the lack of an unambiguous definition of the term "structure" for the purposes of real estate taxation. The legal definition of this term, which has been in force since 2003, is for reference purposes. In the tax act, a list of objects considered buildings was not decided, but a reference to the provisions of the construction law was included. These, in turn, in many cases are imprecise. As a result, this leads to various and often different decisions by tax authorities and administrative courts. This is especially noticeable in the case of building features with a complex structure.

Key words: cableways, ski lifts, taxation, real estate tax, interpretation of the term "construction"

Резюме: Тема налога на имущество горнолыжной инфраструктуры вызывает многочисленные интерпретационные сомнения на стадии применения положений Закона о местных налогах и сборах. Это связано с отсутствием однозначного определения термина «сооружение» для целей налогообложения имущества. Законодательное определение этого термина, действующее с 2003 года, ссылается на другие нормативные предписания. Закон о налогообложении не перечисляет объекты, рассматриваемые как сооружения, а отсылает к положениям строительного права. Во многих случаях последние являются неточными. В результате, налоговые органы и административные суды принимают разные и зачастую несовпадающие решения. Это особенно заметно в случае строительных объектов со сложной структурой.

Ключевые слова: канатные дороги, горнолыжные подъемники, налогообложение, налог на недвижимость, толкование термина «сооружение» 


\section{Wstęp}

Od dłuższego czasu w Polsce trwają zintensyfikowane prace związane $\mathrm{z}$ „uszczelnieniem" systemu podatkowego. Pod pojęciem tym (uszczelnienie) należy rozumieć nie tylko stworzenie odpowiedniego, kompletnego, spójnego, wolnego od luk systemu opodatkowania stabilizującego dochody państwa lub samorządu terytorialnego, ale również wykreowanie korzystnych warunków do wykonywania działalności gospodarczej. Wiele uwagi poświęca się konstrukcji podatków pośrednich i podatków dochodowych, marginalnie zaś traktuje się podatki lokalne, w szczególności podatek od nieruchomości, który w wielu gminach odgrywa kluczową rolę w strukturze dochodów budżetowych, będąc jednocześnie znacznym obciążeniem dla przedsiębiorców ${ }^{1}$.

Jednym z kluczowych przepisów ustawy z dnia 12 stycznia 1991 r. o podatkach i opłatach lokalnych ${ }^{2}$, który wymaga rychłej interwencji ustawodawcy, jest art. 1a ust. 1 pkt 2. Normuje on definicję legalną terminu „budowla” na potrzeby opodatkowania podatkiem od nieruchomości. Obowiązujący, blisko 19 lat, przepis był już kilkukrotnie przedmiotem badania zgodności z Konstytucją (m.in. wyrok TK z dnia 13 września 2011 r., P 33/09³ oraz wyrok TK z 13 grudnia 2017 r., SK 48/154). Nie został jednak wyeliminowany z obrotu prawnego. Na gruncie tej regulacji zapadły dziesiątki tysięcy orzeczeń sądów administracyjnych, w wielu przypadkach sprzecznych $^{5}$.

1 Szerzej na temat uszczelnienia systemu podatkowego zob. Uszczelnienie systemu podatkowego w Polsce, red. D.J. Gajewski, Warszawa 2020, ss. 538.

2 Tekst jednolity: Dz. U. z 2019 r. poz. 1170 z późn. zm. (dalej: ustawa o podatkach i opłatach lokalnych).

3 Dz. U. z 2011 r. Nr 206, poz. 1228.

4 Dz. U. z 2017 r. poz. 2432.

5 Dobrym tego przykładem są wyroki NSA dotyczące opodatkowania transformatorów. I tak w wyroku NSA z dnia 14 maja 2019 r. (II FSK 1563/17, LEX nr 2675702) skład orzekający uznał, iż „stanowisko, że stacje transformatorowe oraz budynki rozdzielni prądu wraz z umieszczonymi w nich urządzeniami elektroenergetycznymi należy zaklasyfikować jako budowle $\mathrm{w}$ rozumieniu ustawy o podatkach i opłatach lokalnych jest nie do zaakceptowania”. Podobne stanowisko wyraził skład orzekający NSA w wyroku z dnia 16 maja 2017 r., II FSK 1062/15, LEX nr 2306835. Natomiast odmienny pogląd zaprezentował NSA w wyroku z dnia 22 lipca 2020 r., II FSK 1064/18, LEX nr 2822029. Zdaniem sądu „w świetle art. 1a ust. 1 pkt 2 ustawy o podatkach i opłatach lokalnych w związku z art. 3 pkt 1 i pkt 3 ustawy - Prawo budowlane, przedmiotowe obiekty - transformatory, urządzenia rozdzielcze oraz baterie akumulatorów stanowią część sieci elektroenergetycznej, a nie część składową budynku. Elementy te należy identyfikować, jako część instalacji (odrębnego obiektu budowlanego), które zapewniają właśnie możliwość użytkowania tejże instalacji (obiektu budowlanego) zgodnie z jej przeznaczeniem. Są zatem niezbędne dla funkcjonowania budowli”. Ten pogląd podzielił skład orzekający NSA w wyroku z dnia 24 listopada 2020 r., II FSK 1317/20, LEX nr 3106525. 
Problemy związane ze stosowaniem tego przepisu wynikają z faktu, że pojęcie budowli nie jest w wystarczający i należyty sposób zdefiniowane w przepisach prawa podatkowego. W zasadzie sprowadza się do odesłań do pojęć zdefiniowanych w ustawie z dnia 7 lipca 1994 r. - Prawo budowlane ${ }^{6}$. Konieczność odwoływania się do regulacji prawa budowlanego powoduje daleko idące wątpliwości, których skutkiem jest niepewność zarówno podatników, jak i organów podatkowych w kwestii, które obiekty należy zaliczać do budowli i w jakim zakresie. Pewność prawa rozumiana jest jako cecha prawa polegająca na tym, że podmiot, do którego prawo się odnosi (adresat normy, obywatel, podatnik), jest w stanie przewidzieć determinowane prawem skutki faktów (stanów rzeczy), w tym czynów (działań i zaniechań) własnych i innych podmiotów. Dla pewności prawa kategorią centralną jest przewidywalność, która jest osiągana w szczególności przez jawność, dookreśloność, jasność i stabilność prawa (w znaczeniu niezmienności, trwałości czy też pokoju prawnego w aspekcie jego stanowienia i stosowania) ${ }^{7}$. Podkreślić należy, że prawo podatkowe stanowi gałąź prawa charakteryzującą się dużym stopniem ingerencji w prawa i wolności jednostki ${ }^{8}$. W związku z tym rezultaty procesu tworzenia i stosowania tego prawa muszą być przewidywalne dla jego adresatów ${ }^{9}$.

Egzemplifikacją „niepewnego prawa” jest definicja budowli uregulowana w art. 1a ust. 1 pkt 2 ustawy o podatkach i opłatach lokalnych. Póki co przepis ten w dalszym ciągu obowiązuje i jak na razie trudno dostrzec nawet jakiekolwiek zalążki projektów zmian w tym zakresie. Kluczową rolę odgrywa zatem proces wykładni tego przepisu. Jak pokazują badania empiryczne sprowadzające się do analizy orzeczeń sądów administracyjnych w tym zakresie, w licznych przypadkach popełniane są błędy w procesie dochodzenia do ustalenia normatywnego znaczenia terminu „budowla”. Obrazują je wyroki dotyczące opodatkowania obiektów o złożonej strukturze, składających się zarówno z elementów mających charakter stricte budowlany (np. fundamenty, konstrukcje wsporcze), jak i niebudowlany (instalacje). Problem ten występuje zwłaszcza przy opodatkowaniu m.in. takich obiektów jak: koleje

6 Tekst jednolity: Dz. U. z 2020 r. poz. 1333.

7 H. Filipczyk, Postulat pewności prawa w wykładni operatywnej prawa podatkowego, Warszawa 2013, s. 21 i nast.

8 B. Brzeziński, Rozstrzyganie watpliwości na korzyść podatnika jako zasada wykładni prawa podatkowego. Próba analizy, w: Ex iniuria non oritur ius. Księga ku czci Profesora Wojciecha Łączkowskiego, red. A. Gomułowicz, J. Małecki, Poznań 2003, s. 255; J. Oniszczuk, Konstytucyjność przepisów prawa podatkowego, Glosa 1995, nr 6, s. 17; H. Filipczyk, Ingerencyjny charakter prawa podatkowego - jedna teza, dwie interpretacje, w: XXV lat przeobrażeń w prawie finansowym i prawie podatkowym - ocena dokonań i wnioski na przyszłość, red. Z. Ofiarski, Szczecin 2014, s. 399 i nast.

9 A. Halasz, Stosowanie definicji stanowionych pojecć prawnych a zasada pewności w prawie podatkowym, w: Zasada pewności w prawie podatkowym, red. A. Kaźmierczyk, A. Franczak, Warszawa 2018, s. 113. 
linowe i wyciągi narciarskie ${ }^{10}$. Kwestia opodatkowania tego typu obiektów rodzi zagorzałe dyskusje w nauce prawa podatkowego ${ }^{11}$.

Przyczynkiem do podjęcia tematyki opodatkowania podatkiem od nieruchomości kolei linowych i wyciągów narciarskich jest wyrok NSA z dnia 9 lipca 2019 r. (II FSK 2693/17) ${ }^{12}$, w którym skład orzekający uznał, że „kolej linowa, wyciąg narciarski i zjeżdżalnia grawitacyjna są urządzeniami technicznymi. Nie podlegają one reżimowi ustawy $\mathrm{z}$ dnia 7 lipca 1994 r. Prawo budowlane, co wyklucza możliwość uznania ich za budowle w rozumieniu art. 1a ust. 1 pkt 2 ustawy o podatkach i opłatach lokalnych Podlegającymi opodatkowaniu budowlami mogą być wyłącznie obiekty stacji narciarskiej, mające charakter obiektów budowlanych w rozumieniu ustawy Prawo budowlane”. Warto podkreślić, iż we wcześniejszych orzeczeniach NSA wydawał odmienne rozstrzygnięcia. Jako przykład można powołać wyrok NSA z dnia 14 lutego 2012 r., w którym sąd wywiódł, iż „kolejka linowa (wyciąg narciarski) jako całość stanowi budowlę w rozumieniu art. 2 ust. 1 pkt 3 ustawy o podatkach i opłatach lokalnych i podlega tym samym opodatkowaniu podatkiem od nieruchomości. Tworzy jedną, techniczno-użytkową całość, rozumianą jako zespół urządzeń przeznaczonych do przewozu osób przy użyciu pojazdów lub urząazeń wyciągowych”. Zdaniem składu orzekającego „przepisy art. 2 ust. 1 pkt 3 ustawy o podatkach i opłatach lokalnych w związku z art. 1a ust. 1 pkt 2 tej ustawy oraz w związku z art. 3 ust. 1 pkt b) ustawy Prawo budowlane należy rozumieć $\mathrm{w}$ ten sposób, że przy rozważaniu opodatkowania podatkiem od nieruchomości stacji narciarskiej opodatkowaniu podlegają wszystkie elementy wyciągu tworzące całość techniczno-użytkową wraz z instalacjami i urządzeniami”'13.

Orzeczenie NSA z 9 lipca 2019 r. jest co najmniej dyskusyjne. Wykładnia dokonana przez skład orzekający NSA pozostaje w sprzeczności z kierunkami wykładni zaprezentowanymi przez TK w powołanym wyroku z $2011 \mathrm{r}$. Zasadniczy problem sprowadza się do odpowiedzi na następujące pytania: czy w świetle przepisów ustawy o podatkach i opłatach lokalnych opodatkowaniu podatkiem od nieruchomości podlegają wyłącznie części budowlane (fundamenty) kolei linowych i wyciągów narciarskich? Czy też przedmiotem opodatkowania jest kolej linowa jako obiekt

10 Problem ten występuje również w sprawach dotyczących opodatkowania sieci gazowych, elektroenergetycznych, wodociągowych, ropociągów itp.

11 Zob. D. Szubielska, Opodatkowanie kolei linowych i wyciagów narciarskich podatkiem od nieruchomości, Przegląd Podatków Lokalnych i Finansów Samorządowych 2011, nr 1, s. 14-16; P. Para, Opodatkowanie infrastruktury narciarskiej, Przegląd Podatków Lokalnych i Finansów Samorządowych 2011, nr 1, s. 8-14. Zob. również P. Para, Czwarty rozbiór budowli, Przegląd Podatków Lokalnych i Finansów Samorządowych 2015, nr 10, s. 6-12.

12 LEX nr 2718015.

13 II FSK 1589/10, LEX nr 1107836. 
kompletny składający się zarówno z części budowlanych, jak i niebudowlanych (instalacji)? W mojej ocenie, co zostanie poniżej wykazane, przedmiotem opodatkowania podatkiem od nieruchomości jest kolej linowa (wyciąg narciarski) jako obiekt kompletny składający się z części budowlanej oraz technicznej.

Podstawową metodą badawczą wykorzystaną w artykule jest metoda jurydyczna (formalno-dogmatyczna). Analizie poddano przepisy prawne, które regulują przedmiotową tematykę przy uwzględnieniu poglądów doktryny oraz orzecznictwa TK oraz sądów administracyjnych.

\section{Granice wykładni terminu „budowla” wynikające z wyroku TK z dnia 13 września 2011 r. P 33 /09}

Procesu wykładni pojęcia budowla na potrzeby opodatkowania podatkiem od nieruchomości nie można zaczynać od terminu o tożsamej nazwie zawartym w ustawie - Prawo budowlane. Podobnie na tym pojęciu wykładnia nie może się skończyć. Wykładnia prawa jest procesem kompleksowym i nie może ograniczać się do językowego znaczenia danego przepisu ${ }^{14}$. Powinna ona uwzględniać również inne regulacje aktu prawnego, w którym przepis ten został umiejscowiony ${ }^{15}$. Dopiero zestawienie poszczególnych przepisów pozwala na zdekodowanie norm w nich zawartych. Ustawa podatkowa odsyła do pojęcia obiektu budowlanego, a nie budowli w rozumieniu przepisów prawa budowlanego ${ }^{16}$.

Punktem wyjścia do rozważań nad wykładnią terminu „budowla” na potrzeby opodatkowania podatkiem od nieruchomości powinien być art. 1a ust. 1 pkt 2 ustawy o podatkach i opłatach lokalnych. Z jego treści wynika, że budowlą jest obiekt budowlany $\mathrm{w}$ rozumieniu przepisów prawa budowlanego niebędący budynkiem lub obiektem małej architektury, a także urządzenie budowlane w rozumieniu przepisów prawa budowlanego związane z obiektem budowlanym, które zapewnia możliwość użytkowania obiektu zgodnie z jego przeznaczeniem. Już tylko pobieżna analiza cytowanego przepisu prowadzi do wniosku, że definicja budowli w prawie podatkowym nie ma charakteru samoistnego $\mathrm{w}$ tym sensie, iż ustawodawca $\mathrm{w}$ jej konstrukcji odsyła do przepisów prawa budowlanego. Nie zdecydował się na enumeratywne wymienienie obiektów (urządzeń), które należy uznać za budowle, lecz

14 R. Mastalski, Miejsce wykładni językowej w procesie stosowania prawa podatkowego, Przegląd Podatkowy 2007, nr 8, s. 7; B. Brzeziński, Wstęp do nauki prawa podatkowego, Toruń 2001, s. 149.

15 E. Smoktunowicz, J. Mieszkowski, Źródła i wykładnia prawa podatkowego, Białystok 1998, s. 65.

16 L. Etel, R. Dowgier, G. Liszewski, B. Pahl, Podatki i opłaty lokalne. Komentarz, Warszawa 2020, s. 52. 
posłużył się techniką odesłania. Ta metoda regulacji służy niewątpliwie zabezpieczeniu przed nadmiernym rozbudowaniem przepisów i jest, przynajmniej w pewnym sensie, „wygodna” dla ustawodawcy ze względu na to, że pozwala wykorzystać obce prawu podatkowemu definicje bez konieczności tworzenia zupełnie nowych terminów języka prawnego. Niesie jednak za sobą ryzyko związane z tym, że określone pojęcia mające ugruntowane znaczenie $\mathrm{w}$ innych gałęziach prawa nie zawsze będą odpowiadały potrzebom opodatkowania.

Ustawodawca definiując budowlę w ustawie o podatkach i opłatach lokalnych, odsyła do określonych pojęć uregulowanych $\mathrm{w}$ prawie budowlanym ${ }^{17}$. Nie ma zatem wątpliwości co do tego, że definicja obiektu budowlanego i budowli uregulowana w przepisach prawa budowlanego, w kontekście art. 3 pkt 1 tej ustawy (do tego przepisu odsyła art. 1a ust. 1 pkt 2 ustawy o podatkach i opłatach lokalnych), ma istotne znaczenie w procesie wykładni przepisów prawa podatkowego, na co zwrócił uwagę TK w wyroku z dnia 13 września 2011 r., i nie można jej pominąć. Wyrok TK ukształtował, przynajmniej tak by się mogło wydawać, praktykę w zakresie opodatkowania podatkiem od nieruchomości budowli i jego analiza jest niezbędna do zrozumienia zasad opodatkowania tego rodzaju obiektów.

Trafnie podkreślił TK, iż „[...] z punktu widzenia standardów konstytucyjnych zakresem przedmiotowym opodatkowania podatkiem od nieruchomości mogą zostać objęte budowle w rozumieniu art. 3 pkt 3 ustawy Prawo budowlane, należące do kategorii obiektów, które expressis verbis wymieniono w tym przepisie, innych przepisach tej ustawy lub załączniku do niej, będące wraz z instalacjami i urządzeniami obiektem budowlanym".

W powołanym orzeczeniu TK jednoznacznie wywiódł, iż budowlą na potrzeby opodatkowania podatkiem od nieruchomości są:

1) budowle w rozumieniu art. 3 pkt 3 ustawy - Prawo budowlane,

2) budowle wymienione w innych przepisach tej ustawy oraz

3) budowle wymienione w załączniku do ustawy - Prawo budowlane.

Powyższe pozwala uznać, iż przy ustalaniu obiektów, które można zaliczyć do kategorii budowli w rozumieniu przepisów ustawy o podatkach i opłatach lokalnych, zasadne jest sięgnięcie nie tylko do definicji „budowla” w prawie budowlanym, ale również pozostałych przepisów tej ustawy oraz załączników, które stanowią jej immanentną część.

Zgodnie $\mathrm{z}$ art. 3 pkt 1 ustawy - Prawo budowlane, w brzmieniu obowiązującym od 28 czerwca 2015 r., obiektem budowlanym jest budynek, budowla bądź obiekt

17 L. Etel, S. Presnarowicz, G. Dudar, Podatki i opłaty lokalne. Podatek rolny. Podatek leśny. Komentarz, Warszawa 2008, s. 36 i nast. 
małej architektury, wraz z instalacjami zapewniającymi możliwość użytkowania obiektu zgodnie z jego przeznaczeniem, wzniesiony z użyciem wyrobów budowlanych. Obiektem budowlanym jest więc budowla wskazana w art. 3 pkt 3 ustawy Prawo budowlane. W myśl tego przepisu pod pojęciem „budowla” należy rozumieć każdy obiekt budowlany niebędący budynkiem lub obiektem małej architektury, jak: obiekty liniowe, lotniska, mosty, wiadukty, estakady, tunele, przepusty, sieci techniczne, wolno stojące maszty antenowe, wolno stojące trwale związane z gruntem tablice reklamowe i urządzenia reklamowe, budowle ziemne, obronne (fortyfikacje), ochronne, hydrotechniczne, zbiorniki, wolno stojące instalacje przemysłowe lub urządzenia techniczne, oczyszczalnie ścieków, składowiska odpadów, stacje uzdatniania wody, konstrukcje oporowe, nadziemne i podziemne przejścia dla pieszych, sieci uzbrojenia terenu, budowle sportowe, cmentarze, pomniki, a także części budowlane urządzeń technicznych (kotłów, pieców przemysłowych, elektrowni jądrowych, elektrowni wiatrowych i innych urządzeń) oraz fundamenty pod maszyny i urządzenia, jako odrębne pod względem technicznym części przedmiotów składających się na całość użytkową.

W przytoczonej definicji terminu „budowla” ustawodawca wymienia bezpośrednio budowle sportowe bez bliższego ich sprecyzowania. Mając jednak na uwadze kierunki wykładni terminu „budowla” sformułowane przez TK w cytowanym wyroku z 2011 r., zasadne jest sięgnięcie do załączników do ustawy - Prawo budowlane. W kategorii V obiektów budowlanych - obiektów sportu i rekreacji wymienione są wprost kolejki linowe oraz wyciągi narciarskie. Tym samym nie powinno być wątpliwości co do tego, że kolej linowa stanowi obiekt budowlany w rozumieniu przepisów prawa budowlanego. Ma to fundamentalne znaczenie na etapie ustalania zakresu przedmiotowego podatku od nieruchomości. Uzasadnione jest to tym, że w „podatkowej” definicji budowli jest bezpośrednie odesłanie do pojęcia „obiekt budowlany" w rozumieniu przepisów prawa budowlanego. Skoro zatem wskazane w załączniku V do ustawy - Prawo budowlane kolejki linowe są obiektem budowlanym, o którym mowa w przepisach prawa budowlanego, to należy je uznać za przedmiot podatku od nieruchomości.

W kontekście powyższego celnie podniósł skład orzekający WSA w Gliwicach w wyroku z dnia 3 kwietnia 2019 r. $^{18}$, iż wprawdzie załącznik do ustawy - Prawo budowlane służy do doprecyzowania czy uszczegółowienia definicji legalnych $\mathrm{z}$ art. 3 prawa budowlanego w zakresie wskazanych w nim obiektów budowlanych, to jednak uwzględniając jego funkcję, stanowi egzemplifikację (przykładowe zilustrowanie) tych obiektów. Służy on mianowicie konkretyzacji wysokości kar

18 I SA/Gl 80/19, LEX nr 2656409. Orzeczenie prawomocne. 
nakładanych za wykonanie budowy niezgodnie z projektem zagospodarowania działki lub terenu, niezgodnie z projektem architektoniczno-budowlanym, z zastosowaniem niewłaściwych wyrobów budowlanych, istotnych dla bezpieczeństwa konstrukcji oraz bezpieczeństwa pożarowego, bez uporządkowania terenu budowy lub bez dokonania rozbiórki obiektów budowlanych pomimo upływu terminu ich rozbiórki, na co wskazują przepisy art. 59f ust. 1 w zw. z art. 59a ust. 2 ustawy - Prawo budowlane.

NSA w cytowanym na wstępie wyroku z dnia 9 lipca 2019 r. w zasadzie pominął fakt wymienienia kolei linowych i wyciągów narciarskich w załączniku do ustawy Prawo budowlane oraz art. 3 pkt 3 tej ustawy wskazujący jako budowlę budowle sportowe. Zdawać należy sobie sprawę, iż cel uregulowań zawartych w załączniku do ustawy - Prawo budowlane jest inny niż opodatkowanie. W tym zakresie nie powinno być wątpliwości, gdyż sama ustawa - Prawo budowlane nie została stworzona na potrzeby ustalania przedmiotu opodatkowania podatkiem od nieruchomości. Niemniej jednak skoro ustawodawca w przepisach ustawy o podatkach i opłatach lokalnych odsyła do tego aktu prawnego przy rozumieniu określonych pojęć, to ustalając kontekst użytych terminów, należy posiłkować się, oczywiście z dużą ostrożnością, pozostałymi regulacjami tego aktu prawnego, zakładając, że tworzą one określoną, spójną całość normatywną ${ }^{19}$.

Warto zwrócić uwagę, iż w załączniku do ustawy - Prawo budowlane prawodawca "nie dzieli” kolei linowych na części budowlane i niebudowlane, jak ma to miejsce $\mathrm{w}$ odniesieniu do elektrowni wiatrowych. W przypadku tych ostatnich wyraźnie zaznaczono, iż obiektem budowlanym jest część budowlana elektrowni wiatrowej. Pozwala to twierdzić, że skoro ustawodawca w art. 3 pkt 3 ustawy - Prawo budowlane wymienił budowle sportowe, a następnie w załączniku do tego aktu prawnego kolejki linowe, a nie ich części budowlane, za obiekt budowlany, a tym samym budowlę w rozumieniu ustawy podatkowej należy uznać całą kolej liniową, a nie jej wybiórcze elementy. Ponadto nie sposób przyjąć, że art. 3 pkt 3 ustawy Prawo budowlane w zakresie dotyczącym części budowlanych urządzeń technicznych (kotłów, pieców przemysłowych, elektrowni jądrowych, elektrowni wiatrowych i innych urządzeń) odnosi się do kolei linowych. Koleje liniowe nie są nawet podobne do urządzeń technicznych wymienionych w tym przepisie. Zakwalifikowanie ich do kategorii budowle sportowe wyklucza zaliczenie ich do części budowlanych urządzeń technicznych.

Odmiennie jednak uznał skład orzekający NSA. W uzasadnieniu wyroku z dnia 9 lipca 2019 r. przyjął, że „art. 3 pkt 1 Prawa budowlanego poprzez wyłączenie 
z definicji obiektu budowlanego «urządzeń technicznych» z którymi obiekt budowlany ma stanowić "całość techniczno-użytkową», zapewniła spójność tego przepisu z art. 3 pkt 3 tej ustawy. Odtąd jako budowla opodatkowaniu podlegają obiekty budowlane nie będące budynkami lub obiektami małej architektury wraz z instalacjami zapewniającymi możliwość użytkowania obiektu zgodnie z jego przeznaczeniem, wzniesione z użyciem wyrobów budowlanych, nie podlegają natomiast opodatkowaniu urządzenia techniczne, chyba że mają części budowlane - wówczas opodatkowaniu jako budowla podlegają ich części budowlane, a nadto opodatkowaniu podlegają fundamenty pod maszyny i urządzenia, jako odrębne pod względem technicznym części przedmiotów składających się na całość użytkową"20.

Należy zwrócić uwagę, iż wyliczenie w art. 3 pkt 3 ustawy - Prawo budowlane obiektów uznawanych za budowle ma charakter przykładowy, ale nie oznacza to, że ten sam obiekt jest tam wymieniony wielokrotnie, pod odmiennymi nazwami. Należy przyjąć, że są tam wyszczególnione przykłady różnych budowli. Czyli budowla sportowa, to nie sieć techniczna czy też maszt antenowy wymienione z nazwy w art. 3 pkt 3 prawa budowlanego. Kolejka linowa (wyciąg narciarski) jako budowla sportowa nie może być też klasyfikowana jako np. wolno stojąca instalacja przemysłowa lub urządzenie techniczne, część budowlana urządzeń technicznych (kotłów, pieców przemysłowych, elektrowni jądrowych, elektrowni wiatrowych i innych urządzeń) czy fundament pod maszyny i urządzenia, jako odrębne pod względem technicznym części przedmiotów składających się na całość użytkową. Nie można zakładać, że na gruncie tego samego przepisu kolejka linowa jest jednocześnie „budowla sportową” i „częścią budowlaną urządzeń technicznych” albo też „wolno stojącą instalacją przemysłową lub urządzeniem technicznym”. Przyjmując, że kolejka linowa jest budowlą sportową, nie można klasyfikować jej jako urządzenia technicznego.

Większość budowli w rozumieniu przepisów prawa budowlanego składa się z konstrukcji budowlanej i części technicznej ${ }^{21}$. Wskazuje na to analiza przykładowego katalogu budowli zawarta w art. 3 pkt 3 ustawy - Prawo budowlane. Ustawodawca posługuje się zwrotem „część budowlana”, aby odróżnić ją od części technicznej np. kotłów, pieców, elektrowni wiatrowych. Robi to jednak w wyraźnie

20 Zdaniem W. Morawskiego koleje linowe są urządzeniem technicznym. Organ podatkowy opodatkowując całość obiektu, ewidentnie naruszałby tę część art. 3 pkt 3 ustawy - Prawo budowlane, zgodnie z którą opodatkowaniu podlegają tylko części budowlane urządzeń technicznych, zob. szerzej W. Morawski, Kolejki linowe, w: Podatek od nieruchomości w orzecznictwie sądów administracyjnych. Komentarz. Linie interpretacyjne, red. W. Morawski, Warszawa 2013, s. 120.

21 L. Etel, Podatki od nieruchomości, Warszawa 2009, s. 15 i nast. 
wskazanych przypadkach (części budowlane urządzeń technicznych i fundamenty pod maszyny i urządzenia). Regułą jest, że w art. 3 pkt 3 ustawy - Prawo budowlane wskazana jest cała budowla, a nie tylko część budowlana danego obiektu. Analiza brzmienia tego przepisu pozwala twierdzić, że za budowle uznaje się, poza wyjątkami w nim wskazanymi, nie tylko część budowlaną, ale także część techniczną. Tylko w szczególnych przypadkach wymienionych w art. 3 pkt 3 powołanej ustawy za budowlę uznaje się jedynie konstrukcję budowlaną. W odniesieniu do pozostałych budowli tam wymienionych należy zakładać, że obie części składają się na budowlę. Nie można zatem twierdzić, że tylko część budowlana kolejki linowej (wyciągu narciarskiego) stanowi budowlę, ponieważ w art. 3 pkt 3 ustawy - Prawo budowlane wskazane są „całe” budowle sportowe, a nie tylko ich „części budowlane”. Obie te części stanowią z reguły całość techniczno-użytkową, które to pojęcie występowało $\mathrm{w}$ definicji budowli do $2015 \mathrm{r}$. Pomimo zmiany definicji w dalszym ciągu nie można utożsamiać budowli jako obiektu budowlanego jedynie z konstrukcją budowlaną. Przedmiotem podatku jest budowla jako konstrukcja budowlana wraz z częścią techniczną, która warunkuje normalne jej funkcjonowanie ${ }^{22}$.

Ustawa z dnia 20 lutego 2015 r. o zmianie ustawy - Prawo budowlane oraz niektórych innych ustaw ${ }^{23}$, mocą której ustawodawca nadał od dnia 28 czerwca 2015 r. nowe brzmienie pojęciu „obiekt budowlany”, nie pozwala na „dzielenie” budowli na części budowlane i niebudowlane. W porównaniu ze stanem prawnym obowiązującym do dnia 28 czerwca 2015 r. ustawodawca definiując budowlę jako jedną z kategorii obiektu budowlanego, „usunął” z jego treści „urządzenia techniczne". Do momentu nowelizacji ustawy - Prawo budowlane obiektem budowlanym była budowla wraz z instalacjami i urządzeniami technicznymi stanowiąca całość techniczno-użytkową. Obecnie zaś (tj. od dnia 28 czerwca 2015 r.) pojęcie obiektu budowlanego obejmuje budowlę wraz z instalacjami zapewniającymi możliwość użytkowania obiektu zgodnie z jego przeznaczeniem.

Proste porównanie dotychczasowego i nowego brzmienia definicji legalnej obiektu budowlanego pozwala stwierdzić, iż ustawodawca z zakresu tego pojęcia wyłączył urządzenia oraz zrezygnował z warunku całości techniczno-użytkowej w odniesieniu do budowli, natomiast do wszystkich trzech kategorii obiektów, tj. budynków, budowli oraz obiektów małej architektury, odniósł warunek ich wzniesienia z użyciem wyrobów budowlanych oraz włączył w zakres definicji instalacje zapewniające możliwość użytkowania obiektu zgodnie z jego przeznaczeniem.

\footnotetext{
22 B. Pahl, Podatki i opłaty lokalne. Teoria i praktyka, Warszawa 2017, s. 97.

23 Dz. U. z 2015 r. poz. 443.
} 
Nie ma wątpliwości co do tego, że skoro w pojęciu obiektu budowlanego jest mowa o budowli, uwzględniając reguły wykładni systemowej wewnętrznej, należy przez to rozmieć budowlę zdefiniowaną w art. 3 pkt 3 ustawy - Prawo budowlane. Każda budowla wskazana w art. 3 pkt 3 ustawy - Prawo budowlane stanowi budowlę w rozumieniu art. 1a ust. 1 pkt 2 ustawy o podatkach i opłatach lokalnych, przy czym powinna być ona rozpatrywana jako obiekt kompletny, tj. łącznie $z$ instalacjami zapewniającymi możliwość użytkowania obiektu zgodnie z jego przeznaczeniem, wzniesiony z użyciem wyrobów budowlanych. Zupełność (kompletność, zdatność do użytku) przedmiotu opodatkowania wynika ewidentnie z treści art. 3 pkt 1 ustawy - Prawo budowlane, do której ustawodawca odsyła w przepisach ustawy podatkowej. Gdyby było inaczej, w art. 1a ust. 1 pkt 2 ustawy o podatkach i opłatach lokalnych byłoby zawarte bezpośrednie odesłanie do art. 3 pkt 3 ustawy - Prawo budowlane (definicja budowli). Umożliwiłoby to „rozbiór” budowli na potrzeby opodatkowania. Sytuacja ta nie ma jednak miejsca w obecnym stanie prawnym, a co za tym idzie, nie ma żadnych podstaw normatywnych - z wyjątkami przewidzianymi w ustawie - do tego, aby w podatku od nieruchomości „dzielić” rzeczy poprzez wyodrębnienie części budowlanych i instalacji, a co za tym idzie, opodatkować wyłącznie pierwsze $z$ nich.

Wprawdzie w zmienionym brzmieniu przepisu art. 3 pkt 1 prawa budowlanego ustawodawca nie używa już pojęcia „całość techniczno-użytkowa”, niemniej jednak wskazuje na obiekt budowlany jako „budowlę wraz z instalacjami”. Na tej właśnie podstawie należy wnioskować o „kompletności” obiektu budowlanego. Składa się on bowiem nie tylko z wyrobów o charakterze stricte budowlanym, ale również instalacji. Dowodzi to, że w dalszym ciągu obiekt budowlany powinien być postrzegany jako obiekt stanowiący spójną całość pomimo braku takiego zapisu. Obiektem budowlanym jest zatem taki obiekt, który spełnia swoje funkcje po technicznym i funkcjonalnym powiązaniu wszystkich elementów. Instalacje mają „zapewnić możliwość użytkowania obiektu zgodnie z jego przeznaczeniem”. Oznacza to, że ustawodawca definiując obiekt budowlany, szczególną wagę przywiązuje do możliwości jego rzeczywistego wykorzystania ${ }^{24}$.

Wobec braku w ustawie - Prawo budowlane legalnej definicji terminu „instalacje” zasadne jest ustalenie jego znaczenia w oparciu o reguły wykładni językowej. Zgodnie ze słownikiem języka polskiego pod pojęciem instalacji należy rozumieć zespół urządzeń technicznych (przewodów i sprzętu) służących do jednolitego celu. Instalacje mają „służyć” obiektowi budowlanemu, tak aby mógł on realizować cel,

24 L. Etel, Opodatkowanie instalacji zapewniajacych funkcjonowanie budowli zgodnie z jej przeznaczeniem, Przegląd Podatków Lokalnych i Finansów Samorządowych 2019, nr 8, s. 16-19. 
do którego został wzniesiony ${ }^{25}$. Tak więc instalacje są terminem ściśle powiązanym z pojęciem obiekt budowlany - jest on budowlą, instalacje zaś umożliwiają jego wykorzystanie zgodnie z przeznaczeniem.

W kontekście powyższego zwrócić należy uwagę na szczególną rolę zarówno instalacji, jak i urządzeń budowlanych względem obiektu budowlanego. „Misją” każdego z nich jest służebny charakter wobec obiektu budowlanego, o czym świadczy bezsporny zapis „[...] umożliwiają wykorzystanie obiektu zgodnie z przeznaczeniem [...]", przy czym instalacja jest część składową obiektu budowlanego, urządzenie budowlane zaś jest „samodzielną" budowlą w rozumieniu przepisów ustawy o podatkach i opłatach lokalnych. Odesłanie przez ustawodawcę do pojęć „obiekt budowlany”, który musi być rozumiany „wraz z instalacjami”, gdyż nie ma podstaw do tego, aby tę część art. 3 pkt 1 prawa budowlanego pomijać, a także do terminu „urządzenie budowlane”, stanowi kolejny, istotny argument przemawiający za pojmowaniem budowli na potrzeby opodatkowania podatkiem od nieruchomości jako obiektu kompletnego, a nie rozbitego na jego pewne elementy ${ }^{26}$.

Instalacje, o których mowa w art. 3 pkt 1 ustawy - Prawo budowlane (pojęcie: obiekt budowlany), stanowią konglomerat powiązanych, współpracujących wzajemnie urządzeń umożliwiających wykorzystanie obiektu budowlanego zgodnie z jego przeznaczeniem. Oczywiście, chodzi tutaj o urządzenia niebędące urządzeniem budowlanym. Zakwalifikowanie danego urządzenia jako urządzenia budowlanego wyklucza traktowanie go za część składową instalacji wymienionej w definicji obiektu budowlanego, pomimo że pełni ona również rolę służebną wobec obiektu budowlanego. Podobnie rzecz ma się z wolnostojącymi instalacjami przemysłowymi. Nie stanowią one instalacji, o której mowa w art. 3 pkt 1 prawa budowlanego, lecz należy je uznać za „samodzielne” budowle w rozumieniu przepisów ustawy o podatkach i opłatach lokalnych oraz prawa budowlanego. Tym samym instalacje, umożliwiające wykorzystanie obiektu budowlanego zgodnie z przeznaczeniem, to zespół współpracujących ze sobą urządzeń innych niż budowlane, których celem jest prawidłowe funkcjonowanie obiektu budowlanego zgodnie z przeznaczeniem, stanowiące jego nierozerwalną część, niebędące jednocześnie „wolnostojącą instalacją przemysłową," która jest samodzielnym obiektem budowlanym.

O „kompletności” obiektu budowlanego świadczą również inne regulacje prawa budowlanego, do których wprawdzie nie odsyła prawodawca w ustawie o podatkach

25 Słownik języka polskiego, red. M Szymczak, t. 1, Warszawa 1978, s. 794.

26 B. Pahl, Opodatkowanie stacji transformatorowych po wyroku Trybunału Konstytucyjnego z 13 grudnia 2017 r. (SK 48/15), Przegląd Podatków Lokalnych i Finansów Samorządowych 2018, nr 4, s. 6-18. 
i opłatach lokalnych, jednakże pozwalają one zrozumieć (urzeczywistnić) przyjęte na potrzeby opodatkowania podatkiem od nieruchomości pojęcie budowli. Dobrym przykładem jest art. 5 ust. 1 tej ustawy. Przepis ten stanowi, że obiekt budowlany jako całość oraz jego poszczególne części, wraz ze związanymi z nim urządzeniami budowlanymi, należy, biorąc pod uwagę przewidywany okres użytkowania, projektować i budować $\mathrm{w}$ sposób określony w przepisach, w tym techniczno-budowlanych, oraz zgodnie z zasadami wiedzy technicznej. Cytowana regulacja wprawdzie normuje kwestie związane z zasadami projektowania i budowy obiektów budowlanych, niemniej jednak obrazuje sposób rozumienia obiektu budowlanego jako „całości”. Zwrócić należy uwagę, iż przepis ten stanowi pewnego rodzaju kontynuację (rozwinięcie) normy z art. 3 pkt 1 prawa budowlanego i jednocześnie wyznacza sposób jego wykładni. Sformułowanie przepisu art. 5 ustawy - Prawo budowlane w ten sposób, tj. „obiekt budowlany jako całości”, utwierdza w przekonaniu, że chodzi tu o „obiekt budowlany wraz z instalacjami umożliwiającymi jego wykorzystanie zgodnie z przeznaczeniem”. Obiekt budowlany jest to obiekt „cały”, a nie tylko jego „budowlane” części. Dlatego też nie ma żadnych podstaw do tego, aby dokonywać „rozbioru” budowli na potrzeby opodatkowania podatkiem od nieruchomości. Ponadto w oparciu o wskazany przepis można wnioskować, że obiekt budowlany to nie zawsze obiekt jednorodny, lecz składający się z „,części”, o czym świadczy zwrot „[...] jego poszczególne części [...]”.

O „kompletności” budowli stanowiącej przedmiot podatku od nieruchomości po zmianie brzmienia terminu „obiekt budowlany” można wnioskować, stosując także wykładnię celowościową. Chodzi o to, że zmiany w przepisach prawa budowlanego ukierunkowane były na stworzenie przejrzystych ram prawnych dla procesu inwestycyjnego w budownictwie. Projektodawca nie odnosi się w nim do kwestii wpływu zmiany definicji obiektu budowlanego na zakres przedmiotowy opodatkowania podatkiem od nieruchomości. Pozwala to stwierdzić, iż zmiana ta ma charakter neutralny z punktu widzenia przepisów prawa podatkowego. Nawet w części uzasadnienia projektu dotyczącej wpływu zmiany przepisów na sektor finansów publicznych ustawodawca stwierdza brak negatywnego wpływu na ten sektor w części dotyczącej zarówno budżetu centralnego, jak i budżetów jednostek samorządu terytorialnego (gmin $)^{27}$. W konsekwencji przyjąć można, iż zamiarem ustawodawcy nie było wprowadzenie zmian, które rzutowałby na zakres opodatkowania. Wydaje się, że nowelizacja przepisów prawa budowlanego miała na celu jedynie doprecyzowanie określonych pojęć oraz dostosowanie polskiego

27 B. Pahl, Glosa do wyroku WSA w Gliwicach z 14 września 2016 r. (I SA/Gl 783/16), Przegląd Podatków Lokalnych i Finansów Samorządowych 2017, nr 4, s. 27-33. 
prawa budowlanego do standardów europejskich, o czym świadczy fakt, że obiekt budowlany powinien być wykonany z użyciem wyrobów budowlanych. W kwestii uznania danych wyrobów za „budowlane” pomocna będzie ustawa z dnia 16 kwietnia 2004 r. o wyrobach budowlanych ${ }^{28}$.

W kontekście podjętego tematu badawczego warto zwrócić uwagę na najnowsze wyroki NSA, powołane na wstępie niniejszej publikacji, dotyczące opodatkowania transformatorów jako elementów sieci elektroenergetycznej. W wyrokach tych NSA odniósł się do definicji obiektu budowlanego po zmianie ustawy - Prawo budowlane z dnia 28 czerwca 2015 r. Jest to tym bardziej istotne, że sieci techniczne wskazane są, podobnie jak budowle sportowe, w art. 3 pkt 3 ustawy - Prawo budowlane, a następnie wymienione wprost w załączniku do tej ustawy.

W wyroku NSA z 24 listopada 2020 r. $^{29}$ sąd trafnie wywiódl, iż „transformatory stanowią niezbędny element sieci elektroenergetycznej. Wymontowanie tych urządzeń uniemożliwiałoby dostarczanie energii elektrycznej do odbiorców o dostosowanym napięciu do poziomu przez nich oczekiwanego. Zgodnie z wymogami techniki i wymogami użytkowymi, transformatory, jak i urządzenia rozdzielcze (służące do rozdziału energii elektrycznej przez skierowanie jej do odbiorców), baterie akumulatorów (służące zapewnieniu zasilania awaryjnego) oraz inne szczegółowo opisane przez biegłego urządzenia (m.in. dławiki, wyłączniki) stanowią całość z liniami elektroenergetycznymi, wspólnie z nimi i innymi elementami sieci umożliwiając prawidłowy przesył energii elektrycznej".

Podobnie w wyroku NSA z dnia 22 lipca 2020 r. $^{30}$ skład orzekający zasadnie odniósł się do zmiany w prawie budowlanym, która nastąpiła w 2015 r. w zakresie pojęcia „obiekt budowlany”. Jest to istotne, ponieważ na kanwie tej nowelizacji dokonuje się „rozbioru” obiektów budowlanych na części budowlane i niebudowlane, jak miało to miejsce także do dnia 28 czerwca 2015 r. Trafne jest w tym zakresie stanowisko NSA wyrażone w tym orzeczeniu, zgodnie z którym „po tej dacie wzmocniono wymogi trwałości fizycznego i funkcjonalnego związku pomiędzy częściami budowlanymi i niebudowlanymi, a warunek zapewnienia użytkowania obiektu zgodnie z jego przeznaczeniem (w miejsce «całości techniczno-użytkowej») przesądził, że instalacje muszą pełnić rolę służebną. Zdaniem Sądu pomimo zmiany definicji nie ma podstaw do twierdzenia, że aktualnie w przypadku budowli instalacje te nie podlegają już opodatkowaniu. Przedmiotem podatku jest budowla

\footnotetext{
28 Tekst jednolity: Dz. U. z 2020 r. poz. 215 z późn. zm.

29 II FSK 1317/20, LEX nr 3106525.

30 II FSK 1064/18, LEX nr 2822029.
} 
jako obiekt budowlany, a zatem budowla wraz z instalacjami, które warunkują jej normalne funkcjonowanie".

Reasumując powyższe, przyjąć trzeba, że wykreślenie z dniem 28 czerwca 2015 r. z definicji obiektu budowlanego zwrotu "całość techniczno-użytkowa” nie zmienia faktu, iż opodatkowaniu podlega, poza wyraźnie wskazanymi w prawie budowlanym przypadkami, zarówno część budowlana, jak i techniczna kolei linowych i wyciągów narciarskich.

\section{Ustawa o dozorze technicznym i wydane na jej podstawie akty wykonawcze a przedmiot opodatkowania podatkiem od nieruchomości}

Istotnym mankamentem analizowanego orzeczenia NSA z dnia 9 lipca 2019 r. $^{31}$ jest oparcie rozstrzygnięcia - de facto określenie przedmiotu opodatkowania podatkiem od nieruchomości - o inne regulacje prawne niż przepisy ustawy o podatkach i opłatach lokalnych oraz ustawy - Prawo budowlane. Sąd skupił się na regulacjach ustawy z dnia 21 grudnia 2000 r. o dozorze technicznym ${ }^{32}$ oraz wydanym na jej podstawie rozporządzeniu Rady Ministrów z dnia 7 grudnia 2012 r. w sprawie rodzaju urządzeń technicznych podlegających dozorowi technicznemu ${ }^{33}$.

Przepisy wskazanych aktów normatywnych nie mogą stanowić podstawy do klasyfikowania danych rzeczy jako potencjalnych przedmiotów opodatkowania podatkiem od nieruchomości. Zakres przedmiotowy tej ustawy sprowadza się do określenia zasad, zakresu i form wykonywania dozoru technicznego oraz jednostek właściwych do jego wykonywania. Wprawdzie w powołanym powyżej orzeczeniu TK z 2011 r. podkreślono, iż „Nie jest wykluczone, że o statusie poszczególnych obiektów i urządzeń współdecydować będą również inne przepisy rangi ustawowej, uzupełniające, modyfikujące czy doprecyzowujące prawo budowlane", niemniej jednak ustawa o dozorze technicznym nie może być uznana za akt prawny uzupełniający czy modyfikujący ustawę - Prawo budowlane. Reguluje ona inną materię niż sprawy związane $\mathrm{z}$ wznoszeniem, rozbiórką obiektów budowlanych. $\mathrm{Z}$ tych też powodów brak jest jakichkolwiek podstaw prawnych do tego, aby w oparciu o przepisy ustawy o dozorze technicznym określać zakres przedmiotowy opodatkowania podatkiem od nieruchomości, tym bardziej że ustawodawca w przepisach ustawy

\footnotetext{
$31 \quad$ II FSK 2693/17, LEX nr 2718015.

32 Tekst jednolity: Dz. U. z 2019 r. poz. 667.

33 Dz. U. z 2012 r. poz. 1468.
} 
o podatkach i opłatach lokalnych oraz w ustawie - Prawo budowlane nie odsyła do tego aktu normatywnego.

Niedopuszczalne jest również stosowanie na potrzeby ustalania zakresu przedmiotowego opodatkowania podatkiem od nieruchomości przepisów aktów wykonawczych (rozporządzeń) ${ }^{34}$. Stosownie do art. 217 Konstytucji RP z dnia 2 kwietnia 1997 r. ${ }^{35}$ nakładanie podatków, innych danin publicznych, określanie podmiotów, przedmiotów opodatkowania i stawek podatkowych, a także zasad przyznawania ulg i umorzeń oraz kategorii podmiotów zwolnionych od podatków następuje w drodze ustawy. Powołany przepis formułuje generalną zasadę, zgodnie z którą obowiązki podatkowe, w tym określenie przedmiotu opodatkowania, powinny wynikać tylko z ustawy (nullum tributum sine lege). W świetle powołanych przepisów Konstytucji RP niedopuszczalne jest zatem określanie przedmiotu opodatkowania w oparciu o definicje funkcjonujące w aktach prawnych innych niż ustawa, w szczególności aktach wykonawczych (rozporządzeniach). Tym samym dokonując wykładni pojęcia „przepisy prawa budowlanego”, użytego w art. 1a ust. 1 pkt 2 ustawy o podatkach i opłatach lokalnych, w zgodzie z Konstytucją RP, uznać należy, iż odesłanie to odnosić się może wyłącznie do przepisów rangi ustawowej ${ }^{36}$. Przedmiot opodatkowania winien być uregulowany wyłącznie w ustawie $\mathrm{e}^{37} \mathrm{i}$ nie ma od tej zasady żadnego wyjątku. Z tych też powodów bez znaczenia w kontekście zakresu przedmiotowego podatku od nieruchomości pozostaje rozporządzenie Rady Ministrów z dnia 7 grudnia 2012 r. w sprawie rodzaju urządzeń technicznych podlegających dozorowi technicznemu ${ }^{38}$.

\section{Zakończenie}

Reasumując, stwierdzić należy, iż pomimo zmiany w dniu 28 czerwca 2015 r. definicji „obiekt budowlany” w ustawie - Prawo budowlane, polegającej na zastąpieniu zwrotu „całość techniczno-użytkowa wraz z instalacjami i urządzeniami” ter-

$34 \mathrm{~W}$ doktrynie prawa podatkowego jednoznacznie wskazuje się, że zakres przedmiotowy opodatkowania powinien wynikać z ustawy, zob. B. Brzeziński, W. Morawski, Glosa do wyroku Trybunału Konstytucyjnego z dnia 13 września 2011 r., P 33/09, Przegląd Orzecznictwa Podatkowego 2012, nr 1, s. $22-28$.

35 Dz. U. z 1997 r. Nr 78, poz. 483 z późn. zm.

36 Wyrok NSA z dnia 27 maja 2010 r., II FSK 2049/09. Wyrok dostępny na: orzeczenia.nsa.gov.pl.

37 Wyrok NSA z dnia 22 czerwca 2017 r., II FSK 1594/15, LEX nr 2325159.

38 B. Pahl, Kontrowersje wokół opodatkowania budowli wewnątrz budynku na przykładzie stacji redukcyjno-pomiarowych gazu, Samorząd Terytorialny 2019, nr 5, s. 30-39. 
minem „wraz z instalacjami umożliwiającymi użytkowanie obiektu zgodnie z jego przeznaczeniem”, brak jest podstaw do „rozbioru” budowli na części budowlane i niebudowlane. Jest to dopuszczalne wyłącznie w zakresie części budowlanych urządzeń technicznych wymienionych w art. 3 pkt 3 ustawy - Prawo budowlane, tj. kotłów, pieców przemysłowych, elektrowni jądrowych, elektrowni wiatrowych.

Koleje linowe i wyciągi narciarskie stanowią budowle sportowe, o których mowa w art. 3 pkt 3 ustawy - Prawo budowlane. Są one wymienione wprost w załączniku do tej ustawy w kategorii V obiektów budowlanych obejmujących obiekty sportu i rekreacji. Zatem brak jest jakichkolwiek podstaw prawnych do tego, aby na potrzeby podatku od nieruchomości ustalać przedmiot opodatkowania w oparciu o przepisy ustawy o dozorze technicznym, a tym bardziej wydanego w oparciu o ten akt prawny rozporządzenia w sprawie rodzaju urządzeń technicznych podlegających dozorowi technicznemu. Dokonywanie wykładni przepisów prawa podatkowego w oparciu o akty prawne rangi podstawowej dyskwalifikuje rezultat tego procesu.

Ustawa o podatkach i opłatach lokalnych $\mathrm{w}$ art. 1a ust. 1 pkt 2 nawiązuje wyłącznie do ustawy - Prawo budowlane, ta zaś przy definiowaniu obiektu budowlanego oraz urządzenia budowlanego nie zawiera odesłania do przepisów normujących sprawy dozoru technicznego. Tym sam nieuzasadnione jest, na etapie ustalania zakresu przedmiotowego podatku od nieruchomości, opieranie się na przepisach innych niż ustawa o podatkach i opłatach lokalnych oraz ustawa - Prawo budowlane.

\section{Bibliografia}

Brzeziński B., Rozstrzyganie wątpliwości na korzyść podatnika jako zasada wykładni prawa podatkowego. Próba analizy, w: Ex iniuria non oritur ius. Księga ku czci Profesora Wojciecha Łaczkowskiego, red. A. Gomułowicz, J. Małecki, Poznań 2003.

Brzeziński B., Wstęp do nauki prawa podatkowego, Torun 2001.

Brzeziński B., Morawski W., Glosa do wyroku Trybunatu Konstytucyjnego z dnia 13 września 2011 r., P 33/09, Przegląd Orzecznictwa Podatkowego 2012, nr 1.

Etel L., Podatki od nieruchomości, Warszawa 2009.

Etel L., Podatek od nieruchomości. Komentarz, Warszawa 2012.

Etel L., Opodatkowanie instalacji zapewniajacych funkcjonowanie budowli zgodnie z jej przeznaczeniem, Przegląd Podatków Lokalnych i Finansów Samorządowych 2019, nr 8.

Etel L., Dowgier R., Liszewski G., Pahl B., Podatki i opłaty lokalne. Komentarz, Warszawa 2020.

Etel L., Presnarowicz S., Dudar G., Podatki i opłaty lokalne. Podatek rolny. Podatek leśny. Komentarz, Warszawa 2008.

Filipczyk H., Postulat pewności prawa w wykładni operatywnej prawa podatkowego, Warszawa 2013. 
Filipczyk H., Ingerencyjny charakter prawa podatkowego - jedna teza, dwie interpretacje, $\mathrm{w}$ : XXV lat przeobrażeń $w$ prawie finansowym i prawie podatkowym - ocena dokonań i wnioski na przyszłość, red. Z. Ofiarski, Szczecin 2014.

Halasz A., Stosowanie definicji stanowionych pojęć prawnych a zasada pewności w prawie podatkowym, w: Zasada pewności w prawie podatkowym, red. A. Kaźmierczyk, A. Franczak, Warszawa 2018.

Mastalski R., Miejsce wykładni językowej w procesie stosowania prawa podatkowego, Przegląd Podatkowy 2007, nr 8.

Oniszczuk J., Konstytucyjność przepisów prawa podatkowego, Glosa 1995, nr 6.

Pahl B., Glosa do wyroku WSA w Gliwicach z 14 września 2016 r. (I SA/Gl 783/16), Przegląd Podatków Lokalnych i Finansów Samorządowych 2017, nr 4.

Pahl B., Kontrowersje wokót opodatkowania budowli wewnątrz budynku na przykładzie stacji redukcyjno-pomiarowych gazu, Samorząd Terytorialny 2019, nr 5.

Pahl B., Opodatkowanie stacji transformatorowych po wyroku Trybunału Konstytucyjnego z 13 grudnia 2017 r. (SK 48/15), Przegląd Podatków Lokalnych i Finansów Samorządowych 2018, nr 4.

Pahl B., Podatki i opłaty lokalne. Teoria i praktyka, Warszawa 2017.

Para P., Opodatkowanie infrastruktury narciarskiej, Przegląd Podatków Lokalnych i Finansów Samorządowych 2011, nr 1.

Para P., Czwarty rozbiór budowli, Przegląd Podatków Lokalnych i Finansów Samorządowych 2015, nr 10.

Smoktunowicz E., Mieszkowski J., Źródła i wykładnia prawa podatkowego, Białystok 1998.

Szubielska D., Opodatkowanie kolei linowych i wyciągów narciarskich podatkiem od nieruchomości, Przegląd Podatków Lokalnych i Finansów Samorządowych 2011, nr 1.

Szymczak M., Słownik języka polskiego, t. 1, Warszawa 1978.

Uszczelnienie systemu podatkowego w Polsce, red. D.J. Gajewski, Warszawa 2020. 